\title{
Spatial dynamics and socioeconomic factors correlated with American cutaneous leishmaniasis in Pernambuco, Brazil from 2008 to 2017
}

\author{
Andréa Flávia Luckwü de Santana Gonçalves ${ }^{[1]}$, Suzanne Santos de Lima ${ }^{[2]}$, \\ Amanda Priscila de Santana Cabral Silva ${ }^{[2],[3]}$ and Celivane Cavalcanti Barbosa ${ }^{[2],[4]}$
}

\author{
[1]. Secretaria de Saúde do Recife, Programa de Residência Multiprofissional em Saúde Coletiva, Recife, PE, Brasil. \\ [2]. Fundação Oswaldo Cruz, Instituto Aggeu Magalhães, Departamento de Saúde Coletiva, Recife, PE, Brasil. \\ [3]. Universidade Federal de Pernambuco, Centro Acadêmico de Vitória, Núcleo de Saúde Coletiva, Vitória de Santo Antão, PE, Brasil. \\ [4] Secretaria de Saúde de Pernambuco, Departamento de Vigilância Epidemiológica da I Regional de Saúde, Recife, PE, Brasil.
}

\begin{abstract}
Introduction: American cutaneous leishmaniasis (ACL) is a public health problem and has been associated with country's territory. We aimed to analyze the spatial dynamics and socioeconomic factors correlated to the incidence of ACL in Pernambuco, Brazil from 2008 to 2017. Methods: A cross-sectional, ecological study was conducted in the Brazilian municipalities. Patient data were obtained from the Health Hazard Notification System (SINAN); indicators and incidence for the total period and for quinquennium were obtained. Socioeconomic factors were analyzed to evaluate the association between the incidence of ACL and presence of bathroom and running water, garbage collection availability, inadequate water supply, sanitation, rural population, per capita income, and vulnerability to poverty. Spatial analysis considered the gross incidence; the Bayesian local empirical method and Moran spatial autocorrelation index were applied using Terra View and QGIS. Results: The incidence of ACL reduced (0.29/100,000 inhabitants per year). Individuals with ACL were young adults (30.3\%), men (60.2\%), brown skinned (62.9\%), rural residents (70.6\%), and less educated (46.7\%); had autochthonous transmission (78.8\%); developed the cutaneous form (97.2\%); had evolution to cure (82.7\%); and were diagnosed using the clinical epidemiological criterion (70.5\%). ACL occurred in the large part of the state and showed heterogeneous distribution, with persistence of two high priority intervention clusters covering Health Regions I, II, III, IV, and XII. Conclusions: Spatial analysis and epidemiological indicators complement each other. The combination of these methods can improve the understanding on ACL occurrence, which will help subsidize planning and enhance the quality and effectiveness of healthcare interventions.
\end{abstract}

Keywords: Neglected diseases. Cutaneous leishmaniasis. Public health surveillance. Spatial analysis.

\section{INTRODUCTION}

Leishmaniasis is a relevant public health issue due to its epidemiological diversity, high incidence, transcendence, and wide geographical distribution; it is one of the most frequent neglected parasitic infections in the world ${ }^{1,2}$. The disease has two clinical forms-visceral leishmaniasis (VL) and American cutaneous leishmaniasis $(\mathrm{ACL})^{3}$.

\footnotetext{
Corresponding Author: Andréa Flávia Luckwü de Santana Gonçalves. e-mail: andrea.luckwu@gmail.com

ACL is widely distributed worldwide, and it is endemic in 87 countries and territories. More than two-thirds of new cases of the patients live in the following nine countries, mainly affecting the socioeconomically disadvantaged people ${ }^{5}$ : Afghanistan, Algeria, Brazil, Colombia, Islamic Republic of Iran, Pakistan, Peru, Saudi Arabia, and Syrian Arab Republic ${ }^{4}$. In the Americas, $73 \%$ of the cases were registered in four countries ${ }^{6}$ : Brazil $(35.1 \%)$ followed by Colombia (15.5\%), Peru (13.3\%), and Nicaragua (8.7\%).

Brazil had an extremely high ACL transmission rate based on the Leishmaniasis Composite Index (17.7/100,000 inhabitants); this index considers the incidence and density of the cases from 2015 to 2017 triennium $^{6}$. The disease is widespread in all Brazilian states and presents various epidemiological profiles and transmission 
patterns associated with socioenvironmental modifications ${ }^{7}$. Approximately $25 \%$ of the country's cases were reported in the Brazilian Northeast, with the highest incidence in Bahia, Maranhão, Ceará, and Pernambuco ${ }^{3}$.

Efforts have been made to reduce the occurrence of ACL. In 2017, the Leishmaniasis Plan of Action for the Americas 2017-2022 was undertaken to reduce morbidity and mortality by strengthening diagnosis, treatment, rehabilitation, prevention, surveillance, and control $^{8}$. In Brazil, the National Surveillance Program for Cutaneous Leishmaniasis was instituted to reduce morbidity, deformities, and deaths ${ }^{3}$. In addition, is a Compulsory Notification Disease; therefore, a structured surveillance is implemented, and its notification makes it possible to measure the magnitude, distribution, and behavior of the disease ${ }^{3}$.

It is worth highlighting that ACL occurs through a close interaction between physical-geographical, biological (vector, host, and parasite), and socioeconomic factors ${ }^{9}$. The first deals with the relationship among health, society, and environment; it is influenced by anthropic actions associated with deforestation and accelerated urbanization process ${ }^{10,11}$. Favored by such conditions, biological factors are responsible for the vector adaptation at the reservoirs and environments; in these spots, dispersion, invasion, and adaptation of the vector to urban/peri-urban areas has been facilitated ${ }^{12,13}$.

The population's socioeconomic conditions can increase the disease burden and prolong its clinical course ${ }^{14-17}$. Studies bespeak that complex dimension of poverty has been an important risk factor for the ACL occurrence-social inequalities and vulnerability, Human Development Index, occupation, and education ${ }^{12,13,18,19}$. Besides, ACL social determinants are closely linked to spatial dynamics such as the area characteristics and the geographical aggregation patterns ${ }^{11}$.

ACL occurrence has been closely related to territory and its complex characteristics. However, as data on this subject are limited, further studies are warranted. Hence, this study aimed to analyze the spatial dynamic and socioeconomic factors associated with ACL incidence in the state of Pernambuco, from 2008 to 2017.

\section{METHODS}

\section{Design and study area}

We conducted a mixed descriptive study, cross-sectional and ecological type. The study aimed to describe the sociodemographic and clinical profile as well as to verify the correlations between exposure and the occurrence of disease in a population belonging to a defined geographical area.

The study was conducted in Pernambuco, located in Brazilian Northeast region, with an area of $98.076 .001 \mathrm{~km}^{2}$ and an estimated population of 9.473 .266 inhabitants $^{20}$. The state is composed of 184 municipalities and a state district (Fernando de Noronha); it is grouped under the logic of regionalization in 12 Health Regions ${ }^{21}$.

In this administrative division, which is heterogeneous, municipalities with similar cultural, sociodemographic, environmental, and economic characteristics are grouped together. The Health Regions II, III, and XII make up Zona da Mata; IV, V, and VI make up Agreste; and VII, IX, X, and XI make up Pernambuco's Sertão. Meanwhile, Health Region VIII is in Pernambuco’s São Francisco.

\section{Data management and analysis}

The secondary data recorded in the Health Hazard Notification System (Sistema de Informação de Notificação de Agravos de Notificação Compulsória [SINAN]) were extracted from the compulsory notification report of ACL; the report is a model standardized by the Ministry of Health. The cases that were selected in this study were confirmed based on the entry types: "new case" and "resident in Pernambuco state" diagnosed between January 1, 2008 and December 31, 2017. A total of 3,943 cases were included in the study. After analyzing the inconsistencies and duplications using the Statistical Package for the Social Sciences version 21.0, $449(11,4 \%)$ cases were excluded from the study.

Population data and cartographic meshes were obtained from the Brazilian Institute of Geography and Statistics (IBGE). Data on socioeconomic indicators were obtained from the Brazilian Human Development Atlas of the United Nations Development Program and the Database of Pernambuco State based on the year of the last census, 2010.

The variables to delineate sociodemographic profile and epidemiological and clinical characteristics profile of ACL patients were analyzed according to completeness in accordance with the criteria provided by Oliveira et al. (2009) ${ }^{22}$. As stated in the postulate, "occupancy" and "HIV-coinfection" were excluded from the analysis as they presented low completeness $(<70 \%)$. Then, absolute and relative frequency rates were calculated.

The incidence rates of ACL in the municipality and in Pernambuco state within the entire time interval (2008-2017) and within the two quinquennium aggregations (2008-2012 and 20132017) were determined. Variations in the incidence percentage were calculated considering the extreme years. The trend of the incidence was verified using Prais-Winsten temporal regression ${ }^{23}$.

To explore the socioeconomic factors and ACL, the zeroadjusted gamma regression model (ZAGA) was used. This model was chosen because the response variable has a relevant number of zero (about $68.5 \%$ ) and because it is strictly positive. The incidence of ACL in 2010 was evaluated because the explanatory variables were obtained from the 2010 IBGE census ${ }^{20}$, which mitigates the possible temporal correlation problem.

The adjusted range model of zeros has three parameters $-\mu$ (location parameter or mean), $\sigma$ (variance component), and $v$ (probability that the modeled variable will obtain values equal to zero). The connection functions for each of the abovementioned parameter are log, log, and logit, respectively ${ }^{24}$.

The socioeconomic variables used were: Percentage of the population with bathroom and running water (bathroom and water), percentage of people in households with inadequate water supply and sanitation (water and sewage), percentage of the population living in the rural area (pop rural), per capita income (income), and percentage of vulnerable to poverty (vulnerable).

Some of these variables have a high correlation; because of this, they were subjected to the dimensionality reduction technique 
using main components ${ }^{25}$. Through the linear combination of the variables that went through this process, a new explanatory variable was created that was normalized for the interval 0-1 and presented as follows, facilitating the interpretation of these new variables:

$$
X^{\prime}=\frac{X-\operatorname{mí} n(X)}{\operatorname{má} x(X)-\operatorname{mí} n(X)}
$$

To form new variables that are more useful for modeling and that can be easily interpreted, two new variables were generated using the equations below:

Infrastructure $=0,61$ (Bathroom and water)-0,56(water and sewage)

$$
\begin{gathered}
-0,55 \text { (Pop.rural); } \\
\text { Poverty=0,71(Vulnerable)-0,71(Income). }
\end{gathered}
$$

The proportions of variance estimated by the component that generates the variables infrastructure and poverty are $79.9 \%$ and $93.1 \%$, respectively.

The infrastructure variable is related to the bathroom and water variables: water and sewage and rural population. It shows the level of infrastructure of municipalities; the higher the percentage of households with piped water and toilets, the greater the value of this variable. As a reflection of the previous fact, the higher the percentage of households in rural areas with inadequate sewage and water supply, the lower the value for this variable. Meanwhile, the new poverty variable measures the level of poverty in the municipalities. That is, the greater the percentage of vulnerable to poverty, the greater its value. Moreover, the greater its value for per capita income, the lower its value.

The software used was R version 3.6.1., GAMLSS packages version 5.1.5 and Prais 1.1.1 for the time trend model.

For spatial analysis, the District of Fernando de Noronha was withdrew from the maps composition because in addition it not present cases in the period; it is an island that do not have bordering municipalities. The gross incidence rates were presented using thematic maps. Seeking to understand the effects of neighboring municipalities on the occurrence of the disease, rates were smoothed using the local empirical Bayesian method, which estimates the coefficients considering the territory of the observed population and the neighboring municipalities.

To verify the existence of spatial dependence, the Global Moran's Spatial Autocorrelation Index was calculated, and the Spatial Autocorrelation Index Moran Place was analyzed, which included three steps: (1) identification of priority areas, using the Moran scattering diagram to compare the spatial dependence of each municipality, where quadrants are generated with the following interpretation-Q1 (high/high) and Q2 (low/low), which indicate positive or similar spatial association points with its neighbors, and Q3 (high/low) and Q4 (low/high), which indicate negative spatial association points, municipalities that have different values from their neighbors ${ }^{26,27}$. This step is visually represented by a BoxMap.
In the second stage, we used the Local Indicators of Spatial Association (LISA) Indicator, which is used to detect regions with local correlation significantly different from the rest of the data, applying the local spatial autocorrelation statistics. The significance assessment is performed by comparing a series of values obtained by permutating the values of neighboring areas ${ }^{28}$.

The third step mixes the zones that have positive spatial relationship and are identified by the BoxMap (with spatial significance above $95 \%$ ) and those with positive spatial relationship identified by LisaMap. The combination of these two groups generated the MoranMap. Priority areas were those made up of MoranMap class Q1, classes Q3 and Q4 are transition areas, where they could evolve into areas of high priority intervention if effective action is not taken.

Maps were elaborated using Terra View 4.2.2 and QGIS 2.18.14 programs.

\section{Ethics considerations}

The research project was approved by the Ethics Committee of the Otávio de Freitas Hospital (opinion number: 2.949.196/2018[CAAE: 91560318.5.0000.5200]).

\section{RESULTS}

\section{Diagnosed cases profile}

From 2008 to 2017, 3,493 new ACL cases were reported in the state of Pernambuco. The most significant incidence rate was in 2009 (5,82/100,000 inhabitants) followed by 2015 (4,9/100,000 inhabitants). Although the incidence peaked in 2015, the incidence decreased to $34,2 \%$ compared with that in the extreme years of the historical series. When analyzing the two quinquennium groups, a $26.6 \%$ reduction was observed in 2008-2012 and a 33,7\% reduction was observed in 2013-2017. Prais-Winsten regression showed that the incidence rate reduced to $0,29 / 100,000$ inhabitants $(p=0,02)$.

By stratifying the incidence rates of municipalities according to Health Region, we found that Region III had the highest incidence. The incidence rates in Regions V, VIII, XI, and XII Health increased compared with those during two 5-year periods, which is different from the results of the regression analysis, even subtle (Table 1).

With regard to the sociodemographic data, individuals affected by the ACL were aged 20 and 39 years $(1,060 ; 30.3 \%)$, were men $(2,102 ; 60.2 \%)$, had brown race/color $(2,198 ; 62.9 \%)$, had less than elementary education $(1,630 ; 46.7 \%)$, and were rural residents $(2,467 ; 70.6 \%)$ (Table 2). Epidemiological clinical variables showed that the cutaneous form of the disease was more common among those infected $(3,395 ; 97.2 \%)$, with autochthonous cases $(2,754 ; 78.8 \%)$, epidemiological clinical criterion confirmation $(2,464 ; 70.5 \%)$, and evolution to cure $(2,887 ; 82.7 \%)$ (Table 2).

\section{Socioeconomic factors correlated with ACL}

Infrastructure and poverty indices (Table 3) increased the estimates of the incidence of ACL. For every 0.01 increase in infrastructure, the incidence estimate increased by $2.6 \%$. For every 0.01 increase in poverty, the estimated incidence of ACL increased by $6.7 \%$. 
TABLE 1: Distribution of annual mean cases of American Cutaneous Leishmaniasis, mean population of the period, and mean incidence according to Pernambuco (PE) Health Region, for the first (2008-2012) and second quinquenium (2013-2017).

\begin{tabular}{|c|c|c|c|c|c|c|}
\hline \multirow{2}{*}{ Health Region } & \multicolumn{2}{|c|}{ Cases } & \multicolumn{2}{|c|}{ Population } & \multicolumn{2}{|c|}{ Incidence } \\
\hline & Quinquenium 1 & Quinquenium 2 & Quinquenium 1 & Quinquenium 2 & Quinquenium 1 & Quinquenium 2 \\
\hline 1 & 157,2 & 87,8 & 3908757 & 4144599 & 4,0 & 2,1 \\
\hline II & 43,4 & 28,2 & 566331 & 592135 & 7,7 & 4,8 \\
\hline III & 133,8 & 94,4 & 574905 & 608681 & 23,3 & 15,5 \\
\hline IV & 53,4 & 30,0 & 1241469 & 1337431 & 4,3 & 2,2 \\
\hline V & 4,6 & 6,8 & 513660 & 537002 & 0,9 & 1,3 \\
\hline $\mathrm{VI}$ & 1,0 & 0,6 & 382602 & 412820 & 0,3 & 0,1 \\
\hline VII & 2,4 & 0,6 & 138719 & 145716 & 1,7 & 0,4 \\
\hline VIII & 0,4 & 1,0 & 434713 & 483040 & 0,1 & 0,2 \\
\hline IX & 7,2 & 6,4 & 327866 & 347718 & 2,2 & 1,8 \\
\hline$x$ & 0,4 & 0,4 & 180780 & 187847 & 0,2 & 0,2 \\
\hline$X I$ & 4,4 & 5,2 & 223879 & 235691 & 2,0 & 2,2 \\
\hline XII & 25,2 & 35,6 & 302767 & 287792 & 8,3 & 11,4 \\
\hline PE & 417 & 280 & 8796448 & 9320472 & 4,7 & 3,0 \\
\hline
\end{tabular}

\section{Spatial analysis}

In 2008-2012 quinquennium, Pernambuco's incidence was 4,9/100,000 inhabitants (0/100,000- 104.8/100,000 inhabitants). In 22 municipalities $(11,9 \%)$ located in Health Regions I, II, III, IV, and XII, the incidence rate was more than 20,0/100,000 inhabitants (Figure 1A). The Bayesian analysis indicates a reduction of these to 17 (9.2\%) (Figure 1B). In Moran Map, 23 municipalities with high intervention priority $(\mathrm{Q} 1)$ were distributed in two clusters: one comprised 19 municipalities (Regions I, III, and IV), while the other comprised four municipalities (Regions II and XII). Intermediate priority areas were located in Health Regions I, II, III, and XII (Figure 1C).

In 2013-2017 quinquennium, incidence was lower $(3,2 / 100,000$ inhabitants) than the first - from $0 / 100,000$ to $95,8 / 100,000$ inhabitants. In 13 (7,1\%), incidence rates in Regions I, II, III, IV, and XII were more than 20,0/100,000 inhabitants (Figure 2A). After Bayesian smoothing, decreased to seven (3.8\%) (Figure 2B). In Moran Map, 19 municipalities were identified as Q1, and they were divided into two clusters: the first comprised 12 municipalities in Regions I and III, while the other comprised 7 municipalities in Regions II and XII. The incidence decreased in the seven municipalities, while increased in three municipalities compared with the respective clusters in the previous period. In addition, six municipalities with intermediate priority were identified in the Regions I, II, and XII (Figure 2C).

\section{DISCUSSION}

This study showed that the most individuals affected by ACL were younger adults, were men, had brown race/color, living in rural areas, and with low educational level. Majority of the individuals acquired the infection at the place of residence; they developed the cutaneous form, diagnostic on the clinical epidemiological criterion and evolved to cure. The disease was present in the large part of the state, but with heterogeneous incidence rates compared with municipalities. There were two high priority intervention clusters covering the municipalities in Health Regions I, II, III, IV and XII.

When analyzing the total period and the first quinquennium, we noted a decrease in the incidence rates, which agrees with the national data ${ }^{3}$. However, there was an increase in the incidence rates in the second period. Such casuistry was observed in Brazil from 1985 onwards, where an increasing number of cases presented transmission peaks every 5 years ${ }^{3}$, corresponding to the increasing incidence observed in the provinces of $\operatorname{Iran}^{29,31,32}$ and Ethiopia ${ }^{30}$. Moreover, the increased incidence may be related to the anthropic actions due to socioeconomic pressure, especially the disordered urbanization that contributes to the domination of the sandfly responsible for transmission of the disease $\mathrm{e}^{10-13}$.

Our analysis showed that ACL was more frequent in brownskinned individuals, those aged 20 and 39 years, and men, which is similar to the profile observed in Brazil ${ }^{33,34}$ and Argentina ${ }^{35}$. Regarding the level of education, most of the patients were unable to complete primary education. This finding corroborates with those of previous studies, indicating the association between the occurrence of neglected infectious parasitic diseases and loweducated populations ${ }^{18,34,35}$, even implying the preventive practice of the disease ${ }^{36}$. 
TABLE 2: Distribution of American cutaneous leishmaniasis cases according to sociodemographic and clinical epidemiological variables, Pernambuco, Brazil, 2008-2017.

\begin{tabular}{|c|c|c|c|}
\hline \multicolumn{2}{|c|}{ Variable } & \multirow{2}{*}{$\frac{\text { Number of cases }}{425}$} & \multirow{2}{*}{$\begin{array}{c}\% \\
12,2\end{array}$} \\
\hline Age range & $<10$ years & & \\
\hline & $10-19$ years & 739 & 21,2 \\
\hline & $20-39$ years & 1.060 & 30,3 \\
\hline & $40-59$ years & 802 & 23,0 \\
\hline & $60-79$ years & 410 & 11,7 \\
\hline & $80+$ years & 57 & 1,6 \\
\hline \multirow[t]{2}{*}{ Gender } & Female & 1.390 & 39,8 \\
\hline & Male & 2.102 & 60,2 \\
\hline \multirow[t]{6}{*}{ Race/color } & White & 638 & 18,3 \\
\hline & Black & 270 & 7,7 \\
\hline & Yellow & 40 & 1,1 \\
\hline & Brown & 2.198 & 62,9 \\
\hline & Indian & 54 & 1,5 \\
\hline & Ignored/blank & 293 & 8,4 \\
\hline \multirow[t]{9}{*}{ Schooling } & Illiterate & 296 & 5,8 \\
\hline & Incomplete elementary school & 1.630 & 46,7 \\
\hline & Complete elementary school & 128 & 2,5 \\
\hline & Incomplete high school & 83 & 1,6 \\
\hline & Complete high school & 92 & 1,8 \\
\hline & Incomplete higher education & 10 & 0,3 \\
\hline & Complete higher education & 10 & 0,2 \\
\hline & Ignored/blank & 966 & 18,9 \\
\hline & Not applicable & 278 & 5,4 \\
\hline \multirow[t]{4}{*}{ Residence area } & Urban & 854 & 24,4 \\
\hline & Rural & 2.467 & 70,6 \\
\hline & Peri-urban & 44 & 1,3 \\
\hline & Ignored/blank & 128 & 3,7 \\
\hline \multirow[t]{2}{*}{ Clinical form } & Cutaneous & 3.395 & 97,2 \\
\hline & Mucosa & 98 & 2,8 \\
\hline \multirow[t]{3}{*}{ Epidemiological classification } & Autochthonous & 2.754 & 78,8 \\
\hline & Allochthonous & 118 & 3,4 \\
\hline & Undetermined & 621 & 17,8 \\
\hline \multirow[t]{2}{*}{ Confirmation criterion } & Laboratory & 1.029 & 29,5 \\
\hline & Clinical-epidemiological & 2.464 & 70,5 \\
\hline \multirow[t]{6}{*}{ Case evolution } & High by cure & 2.887 & 82,7 \\
\hline & Abandon & 41 & 1,2 \\
\hline & Death by ACL & 2 & 0,1 \\
\hline & Death by other causes & 9 & 0,3 \\
\hline & Transference & 10 & 0,3 \\
\hline & Ignored/blank & 544 & 15,6 \\
\hline
\end{tabular}

TABLE 3: Estimates of the zero-adjusted gamma regression model (ZAGA model) for correlation between ACL index in Pernambuco and socioeconomic variables.

\begin{tabular}{|c|c|c|c|}
\hline Parameter & Coefficient & Estimate & $p$-value \\
\hline \multirow{3}{*}{$\mu$} & Intercept & $-3,96$ & 0,01 \\
\hline & Infra & 2,58 & 0,01 \\
\hline & Poverty & 6,47 & 0,00 \\
\hline$\sigma$ & Intercept & 0,02 & 0,78 \\
\hline \multirow{2}{*}{$v$} & Intercept & 2,69 & 0,00 \\
\hline & Infra & $-2,92$ & 0,00 \\
\hline
\end{tabular}




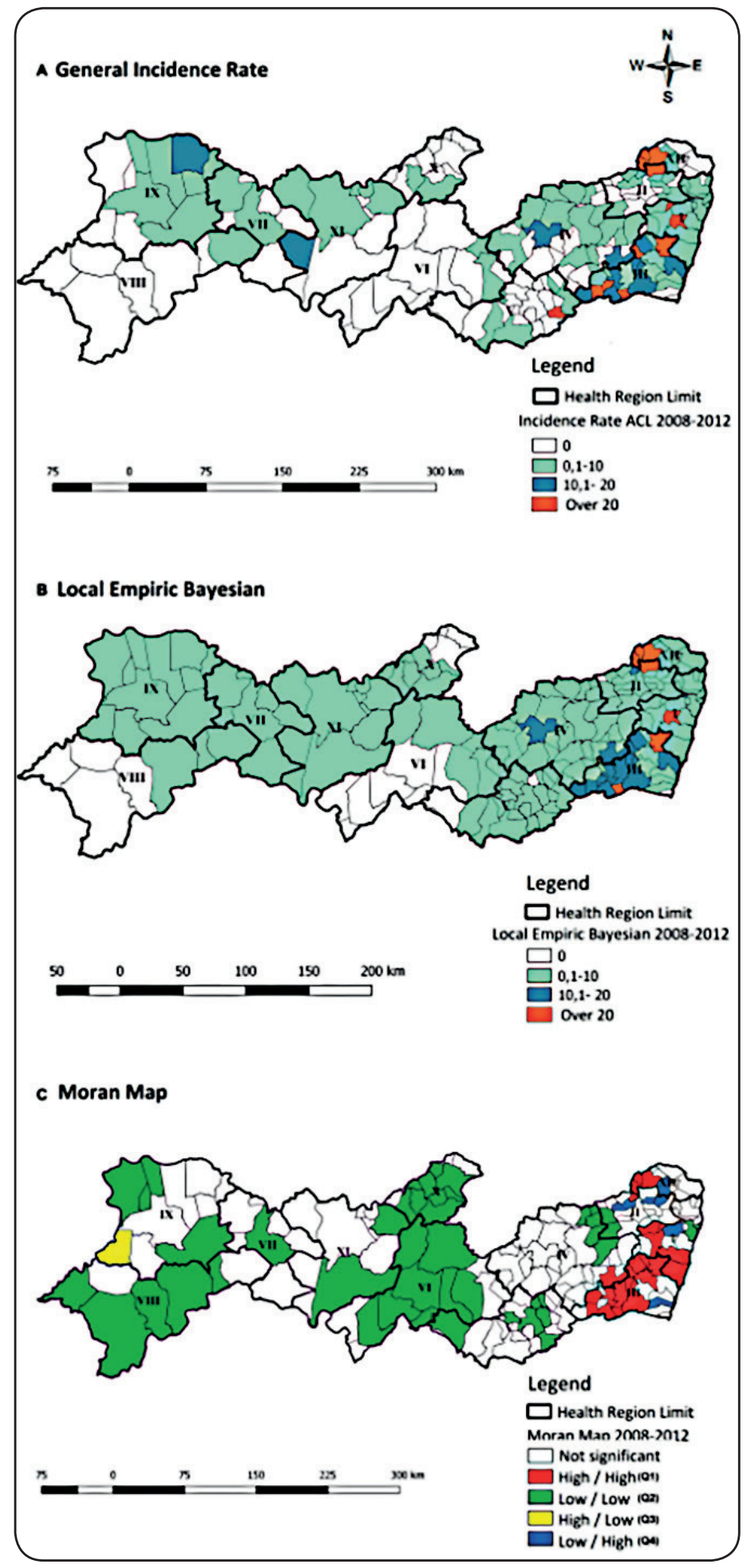

FIGURE 1: Spatial distribution of $A C L$ gross incidence rate (A), smoothed rate by Bayesian local empirical method (B), and Moran Map (C) per 100,000 inhabitants, Pernambuco, Brazil, 2008-2012.

Regarding the residence area, ACL were more common in rural areas with autochthonous transmission. This result is consistent with the literature data, which indicated that the disease was a zoonotic disease; people in contact with forests and rural workers are more predisposed to acquiring ACL as they are more often exposed to the vector and reservoir ${ }^{3,18,37}$. This pattern has been

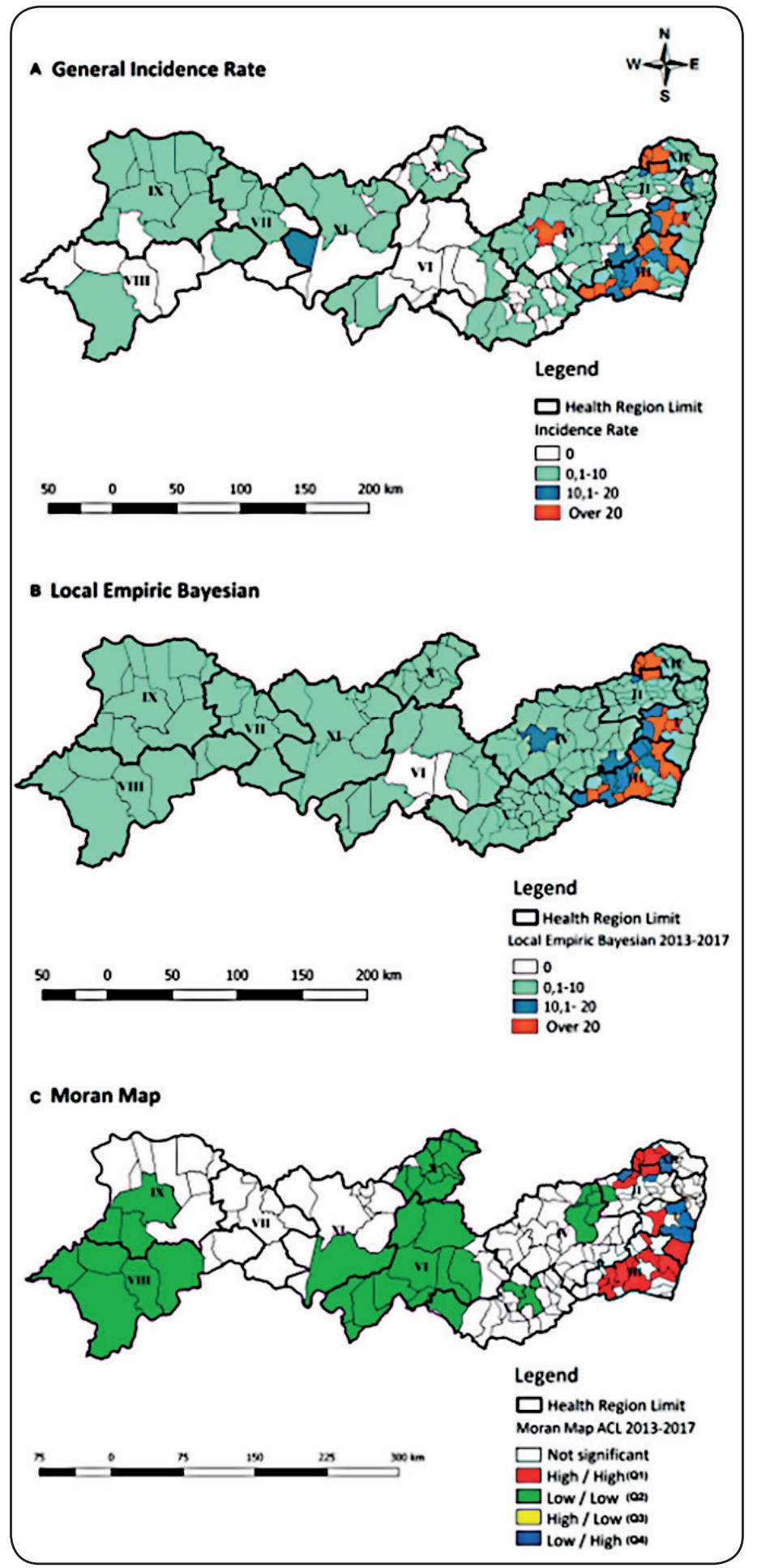

FIGURE 2: Spatial distribution of ACL gross incidence rate (A), smoothed rate by Bayesian local empirical method (B), and Moran Map (C) per 100,000 inhabitants, Pernambuco, Brazil, 2013-2017.

progressively modified; the disease has been occurring in urban and peri-urban areas ${ }^{13,38,39}$ as a result of environmental modifications and demographic changes ${ }^{12,14,40}$.

The cutaneous form were predominant among patients, which is consistent with the results of other studies ${ }^{5,41}$. Choice's confirmation criteria used to diagnose most of our study patients 
were epidemiological and clinical factors; the use of this criterion is based on three aspects-clinical suspicion, impossibility to access laboratory diagnosis methods, and the link with disease transmission areas ${ }^{3}$. That result reflects the need to expand access to complementary parasitological exams, which not only helps detect Leishmania stocks $^{42}$ but also contributes to differential diagnosis ${ }^{43}$.

Evolution to a curative stage was the common outcome. Such evolution occurred spontaneously, which is the reason why the disease was classified as pseudobenign, thus preventing the appropriate diagnosis, treatment, and monitoring of affected patients ${ }^{44}$. Although death due to ACL is rare, the disease reflects a negative impact on patients' daily lives. That may cause individuals to develop incapacitating lesions resulting in psychological, social, and economic issues; affecting individual's interpersonal relationships and life quality ${ }^{45,46}$. According to Bezerra et al. $(2016)^{47}$, in Brazil, the rate of disability due to the occurrence of lesions in 2016 corresponded to an average of 1-2 years of life lost per 100,000 inhabitants, which increases with age.

When we verified the correlation with socioeconomic factors, we found that infrastructure and poverty tend to increase the incidence of ACL. The first factor can be justified by the proliferation and urbanization of the vector ${ }^{10-13,40}$. The second factor presented a greater relative increase, which is congruent with the reports of previous studies conducted in Matara (Sri Lanka) ${ }^{48}$ and India ${ }^{49}$, where low income had a significant association with high incidence.

These findings can be confirmed when the priority areas of intervention are verified, since the Region III presented the highest incidence of ACL and, according to the Human Development Atlas of Brazil ${ }^{50}$, coincided with the areas with high rates of vulnerability to poverty. Health Regions I and IV also had high incidence of ACL; however, these areas had high per capita income ${ }^{50}$. This is possibly because there are socioeconomic differences between the municipalities in the same health region. This finding suggests that inequality is a strong risk factor ${ }^{16,19}$.

The water and sewage situation in many municipalities in Pernambuco is precarious. Regions II and III were the main areas that were not able to avail of the garbage collection service and had inadequate basic sanitation ${ }^{50}$. Valero and Uriarte $(2020)^{51}$ stated that the lack of water supply, sewage system, and garbage collection are risk factors for ACL because poor environmental conditions are good breeding grounds of sandflies.

The spatial analysis revealed two priority clusters for intervention; the first group consisted of municipalities belonging to the Health Regions I, III, and IV, while the second group consisted of municipalities belonging to the Health Regions II and XII. Areas considered transitional were also identified predominantly in these regions. Historically, the region where the clusters were identified, Pernambuco's Zona da Mata, had $60 \%$ of ACL cases in the state ${ }^{46,52,53,54}$. This region geographically corresponds to the area with high concentration of primitive Atlantic Forest remnants; in addition, it presents particularities that favor the disease's spread such as tropical humid climate, rural activities ${ }^{53}$, and accentuated social inequality ${ }^{55}$. Other studies have identified areas that are most vulnerable to the spread of the disease, such as the Minas Gerais (BR), which were subdivided into three clusters (those with rural activities, forest areas, and unusable lands $)^{18}$, and a rural municipality in Venezuela with five clusters (those with a strong influence of environmental factors). Thus, the characteristics of the areas become a focal character in the distribution of the disease ${ }^{56}$. The number of municipalities in the cluster located in Health Regions I, III, and IV were fewer than those in the previous quinquennium. The opposite of it occurred with the cluster of the Health Regions II and XII; this dynamic may be related to the prevention and control of activities as well as the sensitivity to effective notification in municipalities, respectively. It is necessary that such interventions act jointly to guarantee efficacy due to the high transmission potential and disease magnitude ${ }^{3}$. Primarily, it is necessary to identify the disease ecology and control the main reservoirs and vectors besides health education by participating in community programs; as a secondary prevention, early diagnosis and timely treatment should be observed ${ }^{43}$. It is up to the surveillance and healthcare team to improve the information systems application and to involve the healthcare professionals through permanent education.

Moreover, the social determinants of health established by the WHO $(2011)^{57}$ regarding the impact on equity and well-being in the socioeconomic and political context and in the behavioral, biological and psychosocial context must be highlighted. The inequalities in these structures generate an environment conducive to the reproduction of neglected diseases, such as the ACL. Thus, to improve the health situation, it is necessary to reduce inequities; improve social performance, such as well-being, education, social cohesion and conservation of the environment; increase productivity; and improve economic development.

The data described in this study were extracted from SINAN, an important system for epidemiological information knowledge. Notwithstanding, secondary data should be carefully interpreted, as it may lead to inconsistencies during information processing and underreporting. To address the limitations, the duplicity and incompleteness of the cases were analyzed. Epidemiological bias may exist in the attempt to interpret the heterogeneity of the distribution of rates in the geographical space and the socioeconomic indicators analyzed.

Therefore, this study shows that combining spatial analysis tools and epidemiological indicators optimizes the exploitation of the ACL temporal space, helping to locate risk areas, and subsidizing the planning of prevention and control actions in the priority and intermediate areas of intervention.

The disease has been persistent in the Pernambuco's Zona da Mata, which is in the Health Regions I, II, III, and XII; hence, it is important to establish and strengthen the indissociable measures of preventive, diagnostic, and control against the disease in this region. Moreover, the incidence rates in certain areas should be monitored. A few studies reported the association between ACL distribution and socioeconomic risk factors; however, further investigations should be conducted to determine the other risk factors of this neglected disease and thus establish the appropriate health and social policies, aimed improved the disease control.

\section{ACKNOWLEDGMENTS}

The authors would like to thank the Pernambuco State Department of Health for providing the data used in this study. 


\section{FINANCIAL SUPPORT}

Funding for this research was provided by the authors.

\section{AUTHORS' CONTRIBUTION}

AFLSG was responsible for the project, participated in all planning, data collection, data analysis, map drawing, writing, and approval of the final version of the manuscript; SSL: Participated in all planning, data collection, data analysis, map drawing, writing and approval of the final version of the manuscript. APSCS participated in the critical review of the content and approval of the final version of the manuscript. CCB participated in all planning, data collection, data analysis, writing, critical review of the content, and approval of the final version of the manuscript.

\section{CONFLICT OF INTEREST}

The authors declare that there is no conflict of interest.

\section{REFERENCES}

1. World Health Organization - WHO. Neglected, Tropical and Vector Borne Diseases [Internet]. [cited 2018 May 10]. Available from: https:// www.paho.org/hq/index.php?option=com_content\&view $=$ article \&id= 5398:neglected-tropical-vector-borne-diseases\&Itemid=1074\&lang=en

2. Tolezano JE. O Presente E O Futuro. Hansen Int [Internet]. 2015;40(1):1-2. Available from: http://search.ebscohost.com/ login.aspx?direct $=$ true $\&$ site $=e d s-l i v e \& d b=e d$ srca $\& A N=$ rcaap. openAccess.10400.6.748.

3. Brasil. Ministério da Saúde. Secretaria de Vigilância em Saúde. Departamento de Vigilância das Doenças transmissíveis. Manual de vigilância da leishmaniose tegumentar [recurso eletrônico] Ministério da Saúde, Secretaria de Vigilância em Saúde, Departamento de Vi. 2017. 189 p.

4. Bailey MS, Lockwood DNJ. Cutaneous leishmaniasis. Clin Dermatol [Internet]. 2007 Mar 1 [cited 2019 Apr 12];25(2):203-11. Available from: https://www.sciencedirect.com/science/article/pii/ S0738081X0600071X?via\%3Dihub.

5. Burza S, Croft SL, Boelaert M. Leishmaniasis. Lancet (London, England) [Internet]. 2018 Sep 15 [cited 2019 Apr 12];392(10151):951-70. Available from: http://www.ncbi.nlm.nih.gov/pubmed/30126638.

6. Organização PanAmericana de Saúde, Organização Mundial da Saúde. Leishmanioses - Informe Epidemiológico das Américas No 7 - Março, 2019. In [cited 2019 Apr 12]. Available from: http://iris.paho.org/xmlui/ bitstream/handle/123456789/50505/2019-cde-leish-informe-epi-dasamericas.pdf.sequence $=2 \&$ isAllowed $=y$.

7. Vasconcelos PP, Araújo NJ de, Rocha FJS. Ocorrência e comportamento sociodemográfico de pacientes com leishmaniose tegumentar americana em Vicência, Pernambuco, no período de 2007 a 2014. Semin Ciências Biológicas e da Saúde [Internet]. 2017 Dec 18 [cited 2019 Apr 22];38(1):105. Available from: http://www.uel.br/revistas/uel/index.php/ seminabio/article/view/27644.

8. World Health Organization - WHO. Información general: Leishmaniasis [Internet]. [cited 2018 May 10]. Available from: https:/www.paho.org/hq/ index.php?option $=$ com content\&view $=$ article $\&$ id $=9417$ :2014-informaciongeneral-leishmaniasis\&Itemid=40370\&lang=en.

9. Almeida Neto WS de, Universidade Federal do Piauí. Teresina PB. Aspectos clínicos, epidemiológicos e laboratoriais da Leishmaniose tegumentar americana em hospital de referência de Teresina, Piauí. 2015 [cited 2019 Apr 22]; Available from: https://www.arca.fiocruz.br/ handle/icict/13813.
10. Carvalho AI De. Determinantes sociais, econômicos e ambientais da saúde. A saúde no Bras em 2030 - prospecção estratégica do Sist saúde Bras Popul e Perf sanitário [online] [Internet]. 2013;2:19-38. Available from: http://books.scielo.org/id/8pmmy/pdf/noronha-9788581100166-03.pdf.

11. Amaro RR, Costa WA. Transformações Socioespaciais No Estado Do Rio De Janeiro Enquanto Determinante Social Da Saúde: No Contexto Das Leishmanioses. Hygeia - Rev Bras Geogr Médica e da Saúde. 2017;13(26):198-210.

12. Silva AF da S, Latorre M do RD de O, Galati EAB. Fatores relacionados à ocorrência de Leishmaniose Tegumentar no Vale do Ribeira. Rev Soc Bras Med Trop [Internet]. 2010 [cited 2019 Apr 20];43(1):46-51. Available from: http://www.scielo.br/pdf/rsbmt/v43n1/a11v43n1.pdf

13. Detoni MB, Lima DM, Silva TP da, Machado LF, Tomiotto-Pellissier F, Costa IN, et al. Temporal and spatial distribution of American tegumentary leishmaniasis in north Paraná: 2010-2015. Rev Soc Bras Med Trop [Internet]. 2019 Feb 14 [cited 2019 Apr 22];52(0). Available from: http://www.scielo.br/scielo.php?script=sci_arttext\&pid=S003786822019000100609\&lng=en\&tlng=en.

14. Rodrigues MG de A, Sousa JD de B, Dias ÁLB, Monteiro WM, Sampaio V de S. The role of deforestation on American cutaneous leishmaniasis incidence: spatial-temporal distribution, environmental and socioeconomic factors associated in the Brazilian Amazon. Trop Med Int Heal [Internet]. 2019 Mar 1 [cited 2019 Apr 22];24(3):348-55. Available from: http://doi.wiley.com/10.1111/tmi.13196.

15. Rangel EF, Costa SM, Carvalho BM. Mudanças Ambientais e o Espalhamento Geográfico da Leishmaniose Tegumentar Americana no Brasil. In: IntechOpen, editor. Leishmaniose - Tendências em Epidemiologia, Diagnóstico e Tratamento [Internet]. 2014. Available from: https://www.intechopen.com/books/leishmaniasis-trends-inepidemiology-diagnosis-and-treatment/ambiental-changes-and-thegeographic-spreading-of-american-cutaneous-leishmaniasis-in-brazil.

16. El Alem MMM, Hakkour M, Hmamouch A, Halhali M, Delouane B, Habbari K, et al. Risk factors and prediction analysis of cutaneous leishmaniasis due to Leishmania tropica in Southwestern Morocco. Infect Genet Evol [Internet]. 2018 Jul [cited 2019 Mar 22];61:84-91. Available from: http://www.ncbi.nlm.nih.gov/pubmed/29578084.

17. Mashayekhi-Ghoyonlo V, Kiafar B, Rohani M, Esmaeili H, ErfanianTaghvaee MR. Correlation between Socioeconomic Status and Clinical Course in Patients with Cutaneous Leishmaniasis. J Cutan Med Surg [Internet]. 2015 Jan 1 [cited 2019 Apr 22];19(1):40-4. Available from: http://journals.sagepub.com/doi/ 10.2310/7750.2014.13216.

18. Temponi AOD, Brito MG de, Ferraz ML, Diniz S de A, Cunha TN da, Silva MX. Ocorrência de casos de leishmaniose tegumentar americana: uma análise multivariada dos circuitos espaciais de produção, Minas Gerais, Brasil, 2007 a 2011. Cad Saude Publica [Internet]. 2018 Feb 19 [cited 2018 May 14];34(2). Available from: http://www.scielo.br/scielo.php?script=sci_ arttext\&pid=S0102-311X2018000205013\&lng=pt\&tlng=pt.

19. Rodríguez-Morales AJ, Pascual-González Y, Benítez JA, LópezZambrano MA, Harter-Griep R, Vilca-Yengle LM, et al. Asociación entre la incidencia de leishmaniosis cutánea y el índice de desarrollo humano y sus componentes en cuatro estados endémicos de Venezuela. Rev Peru Med Exp Salud Publica [Internet]. 2010 Mar [cited 2018 Mar 14];27(1):22-30. Available from: http://www.scielosp.org/scielo. php?script=sci_arttext\&pid=S1726-46342010000100005\&lng=es\&nr $\mathrm{m}=\mathrm{iso} \& \operatorname{lng}=\mathrm{es}$.

20. IBGE | Portal do IBGE [Internet]. [cited 2018 Mar 17]. Available from: https://www.ibge.gov.br/.

21. Pernambuco. Secretaria Estadual de Saúde. Plano estadual de saúde: 2016-2019 [Internet]. 2016 [cited 2018 Mar 17]. 338 p. Available from: https://www.conass.org.br/pdf/planos-estaduais-de-saude/PE_PES2016-2019-FINAL_23_12_2016-1.pdf. 
22. Oliveira MEP, Soares MR de AL, Costa M da CN, Mota ELA. Avaliação da completitude dos registros de febre tifóide notificados no Sinan pela Bahia. Epidemiol Serv Saúde [Internet]. 2009 [cited 2018 Nov 20];18(3):219-26. Available from: http://scielo.iec.gov.br/pdf/ess/ v18n3/v18n3a04.pdf.

23. Prais, S. J. and Winsten, C. B. (1954): Trend Estimators and Serial Correlation. Cowles Commission Discussion Paper, 383 (Chicago).

24. Stasinopoulos D. M. Rigby R.A. (2007) Generalized additive models for location scale and shape (GAMLSS) in R. Journal of Statistical Software, Vol. 23, Issue 7, Dec 2007, http://www.jstatsoft.org/v23/i07.

25. Mardia, K. V., J. T. Kent and J. M. Bibby (1979). Multivariate Analysis, London: Academic Press.

26. Câmara G, Carvalho MS, Cruz OG, Correa V. Análise espacial de dados geográficos: Cap. 5, análise espacial de áreas. Brasília, EMBRAPA, 2004 [Internet]. Disponível em: http://www.dpi.inpe.br/gilberto/livro/ analise/cap5-areas.pdf (Acessado em 17 de abril de 2017).

27. Lal A, Hales S. Heterogeneity in hotspots: spatio-temporal patterns in neglected parasitic diseases. Epidemiol Infect [Internet]. 2015 Feb 12 [cited 2018 Dez 20];143(3):631-9. Available from: https://www. cambridge.org/core/product/identifier/S0950268814001101/type/ journal_article.

28. Anselin L, Bao S. Exploratory Spatial Data Analysis Linking SpaceStat and ArcView. In Springer, Berlin, Heidelberg; 1997 [cited 2018 Dez 23]. p. 35-59. Available from: http://www.springerlink.com/ index/10.1007/978-3-662-03499-6_3.

29. Akhlagh A, Salehzadeh A, Zahirnia AH, Davari B. 10-Year Trends in Epidemiology, Diagnosis, and Treatment of Cutaneous Leishmaniasis in Hamadan Province, West of Iran (2007-2016). Front Public Heal. 2019;7(March):1-7.

30. Gebremichael D. Zoonotic impact and epidemiological changes of leishmaniasis in Ethiopia. Open Vet J [Internet]. 2018 [cited 2019 Jan 15];8(4):432-40. Available from: http://www.ncbi.nlm.nih.gov/ pubmed/30538935.

31. Jorjani O, Mirkarimi K, Charkazi A, Shahamat YD, Mehrbakhsh Z, Bagheri A. The epidemiology of cutaneous leishmaniasis in Golestan Province, Iran: A cross-sectional study of 8-years. Parasite Epidemiol Control [Internet]. 2019 May [cited 2019 Jan 25];5:e00099. Available from: http://www.ncbi.nlm.nih.gov/pubmed/30937404.

32. Salimi M, Jesri N, Javanbakht M, Farahani LZ, Shirzadi MR, Saghafipour A. Spatio-temporal distribution analysis of zoonotic cutaneous leishmaniasis in Qom Province, Iran. J Parasit Dis [Internet]. 2018 Dec 13 [cited 2019 Jan 22];42(4):570-6. Available from: http:// www.ncbi.nlm.nih.gov/pubmed/30538355.

33. Grangeiro Júnior CRP, Pimentel JVC, Teixeira Júnior AG, Jesus AF de, Galvão TCF, Souza LAA de, et al. American cutaneous leishmaniasis in a northeast Brazilian city: clinical and epidemiological features. Rev Soc Bras Med Trop [Internet]. 2018 Dec [cited 2019 Jan 30];51(6):83742. Available from: http://www.scielo.br/scielo.php?script=sci arttext\&pid=S0037-86822018000600837\&lng=en\&tlng=en.

34. Karagiannis-Voules D-A, Scholte RGC, Guimarães LH, Utzinger J, Vounatsou P. Bayesian Geostatistical Modeling of Leishmaniasis Incidence in Brazil. Reithinger R, editor. PLoS Negl Trop Dis [Internet]. 2013 May 9 [cited 2019 Jan 20];7(5):e2213. Available from: http://dx.plos. org/10.1371/journal.pntd.0002213.

35. Bustos MFG, González-Prieto G, Ramos F, Mora MC, Hashiguchi Y, Parodi C, et al. Clinical and epidemiological features of leishmaniasis in northwestern-Argentina through a retrospective analysis of recent cases. Acta Trop [Internet]. 2016 Feb [cited 2019 Feb 03];154:125-32. Available from: http://www.ncbi.nlm.nih.gov/pubmed/26611809.
36. Borges BKA, Silva JA da, Haddad JPA, Moreira ÉC, Magalhães DF de, Ribeiro LML, et al. Avaliação do nível de conhecimento e de atitudes preventivas da população sobre a leishmaniose visceral em Belo Horizonte, Minas Gerais, Brasil. Cad Saude Publica [Internet]. 2008 Apr [cited 2019 Feb 12];24(4):777-84. Available from: http://www. scielo.br/scielo.php?script=sci_arttext\&pid=S0102-311X20080004000 07\&lng=pt\&tlng=pt.

37. Pezente LG, Benedetti MSG. Epidemiological profile of American cutaneous Leishmaniasis in the Stateof Roraima, Amazonia, Brazil, between 2007 and 2016. Brazilian J Heal Rev [Internet]. 2019 Mar 12 [cited 2019 Feb 12];2(3):1734-42. Available from: http://www. brazilianjournals.com/index.php/BJHR/article/view/1458/1558.

38. Benício E, Cordeiro M, Monteiro H, Moura MAS, Oliveira C, Gadelha EPN, et al. Sustained presence of cutaneous leishmaniasis in urban Manaus, the largest human settlement in the Amazon. Am J Trop Med Hyg. 2015;93(6):1208-13.

39. Silva RCR, Silva AS, Guimarães, Sousa SS da S, Bezerra JMT, Rebêlo JMM, et al. Occurrence of Phlebotominae (Diptera: Psychodidae) in Urban Leishmaniasis Transmission Foci in North-Eastern Brazil. J Med Entomol [Internet]. 2019 Jan 8 [cited 2019 Feb 15];56(1):247-53. Available from: http://www.ncbi.nlm.nih.gov/pubmed/30380076.

40. Negrão GN, Ferreira MEMC. Considerações sobre a leishmaniose tegumentar americana e sua expansão no território brasileiro. 2014 [cited 2019 Feb 15];(1):147-68. Available from: http://ojs.uem.br/ojs/ index.php/Percurso/article/viewFile/21375/13163.

41. Oliveira da dos S, Figueiredo MF, Braga PET. Perfil epidemiológico dos casos de Leishmaniose Tegumentar Americana na Serra da Meruoca, Ceará, no período de 2001 a 2012 [Internet]. Vol. 13, SANARE - Revista de Políticas Públicas. Shogakukan; 2019 [cited 2019 Feb 15]. Available from: https://sanare.emnuvens.com.br/sanare/article/view/571.

42. Handler MZ, Patel PA, Kapila R, Al-Qubati Y, Schwartz RA. Cutaneous and mucocutaneous leishmaniasis. J Am Acad Dermatol [Internet]. 2015 Dec [cited 2019 Mar 07];73(6):911-26. Available from: http://www. ncbi.nlm.nih.gov/pubmed/26568336.

43. Tirelli F, Vernal S, Roselino AM. Final diagnosis of 86 cases included in differential diagnosis of American tegumentary leishmaniasis in a Brazilian sample: a retrospective cross-sectional study. An Bras Dermatol [Internet]. 2017 Oct [cited 2019 Mar 09];92(5):642-8. Available from: http://www.scielo.br/scielo.php?script=sci_arttext\&pid=S036505962017000500642\&lng=en\&tlng=en.

44. Laboudi M, Sahibi H, Elabandouni M, Nhammi H, Ait Hamou S, Sadak A. A review of cutaneous leishmaniasis in Morocco: A vertical analysisto determine appropriate interventions for control and prevention. Acta Trop [Internet]. 2018 Nov [cited 2019 Mar 20];187:275-83. Available from: http://www.ncbi.nlm.nih.gov/pubmed/30056074.

45. Bennis I, Thys S, Filali H, De Brouwere V, Sahibi H, Boelaert M. Psychosocial impact of scars due to cutaneous leishmaniasis on high school students in Errachidia province, Morocco. Infect Dis Poverty [Internet]. 2017 Dec 7 [cited 2019 Mar 20];6(1):46. Available from: http://www.ncbi.nlm.nih.gov/pubmed/28385151.

46. Bedoya SJ, Cristina da Costa Martins A, Pimentel MIF, Souza CV. Estigmatização social pela leishmaniose cutânea no estado do Rio de Janeiro, Brasil. Reciis - Rev Eletron Comun Inf Inov Saúde [Internet]. 2017;11(3): 1-12. Available from: https://www.reciis.icict.fiocruz.br/index.php/reciis.

47. Bezerra JMT, de Araújo VEM, Barbosa DS, Martins-Melo FR, Werneck GL, Carneiro M. Burden of leishmaniasis in Brazil and federated units, 1990-2016: Findings from Global Burden of Disease Study 2016. van Griensven J, editor. PLoS Negl Trop Dis [Internet]. 2018 Sep 6 [cited 2019 Mar 20];12(9):e0006697. Available from: http://dx.plos. org/10.1371/journal.pntd.0006697. 
48. Kariyawasam KK, Edirisuriya C S, Senerath U, Hensmen D, Siriwardana HV, Karunaweera ND. Characterisation of cutaneous leishmaniasis in Matara district, southern Sri Lanka: evidence for case clustering. Pathog Glob Health. 2015;109(7):336-43. doi:10.1179/20477 73215Y.0000000032.

49. Aara N, Khandelwal K, Bumb RA, Mehta RD, Ghiya BC, Jakhar R, et al. Estudo clínico-epidemiológico da leishmaniose cutânea em Bikaner, Rajasthan, Índia. Am J Trop Med Hyg. 2013; 89: 111-5.

50. Atlas Brasil. Atlas do Desenvolvimento Humano Municipal 2010. Disponível em: <http://www.atlasbrasil.org.br/2013/>.

51. Valero NNH, Uriarte M. Environmental and socioeconomic risk factors associated with visceral and cutaneous leishmaniasis: a systematic review. Parasitol Res. 2020;119(2):365-84. doi:10.1007/s00436-01906575-5.).

52. Brandão-Filho SP, Carvalho FG de, Brito MEF de, Almeida F de A, Nascimento LA. American cutaneous leishmaniasis in Pernambuco, Brazil: eco-epidemiological aspects in Zona da Mata region. Mem Inst Oswaldo Cruz [Internet]. 1994 Sep [cited 2019 Apr 02];89(3):445-9. Available from: http://www.scielo.br/scielo.php?script=sci_arttext\&pid=S007402761994000300028\&lng=en\&tlng=en.

53. Brandão-Filho SP, Campbell-Lendrum D, Brito MEF, Shaw JJ, Davies CR. Epidemiological surveys confirm an increasing burden of cutaneous leishmaniasis in north-east Brazil. Trans R Soc Trop Med Hyg [Internet].
1999 Sep 1 [cited 2019 Apr 02];93(5):488-94. Available from: https:// www.sciencedirect.com/science/article/pii/S0035920399903462.

54. Brito MEF de, Andrade MS, Dantas-Torres F, Rodrigues EHG, Cavalcanti M de P, Almeida AMP et al. Cutaneous leishmaniasis in northeastern Brazil: a critical appraisal of studies conducted in State of Pernambuco. Rev Soc Bras Med Trop [Internet]. 2012 Jul 26 [cited 2019 Apr 02];45(4):425-9. Available from: http://www.scielo.br/scielo. php?script=sci_arttext\&pid=S0037-86822012000400002\&lng=en\&tln $\mathrm{g}=\mathrm{en}$.

55. Scott RP. Família, Gênero e Saúde na Zona da Mata de Pernambuco. In: Anais da Reunião Brasileira de Estudos Populacionais. 2016. p. 1071-93.

56. Rodríguez E-M, Díaz F, Pérez M-V. Spatio-temporal clustering of American Cutaneous Leishmaniasis in a rural municipality of Venezuela. Epidemics [Internet]. 2013 Mar [cited 2019 Feb 4];5(1):11-9. Available from: http://www.ncbi.nlm.nih.gov/pubmed/23438427.

57. Organização Mundial da Saúde. Diminuindo as diferenças: a prática das políticas sobre determinantes sociais da saúde. [Documento de Discussão]. Rio de Janeiro, Conferência Mundial sobre Determinantes Sociais da Saúde, 19-21 Outubro; 2011. 47p. 